\title{
28 Research Square \\ Bio-Sequence Stratigraphy of Asmari Formation in the Southeast of Norabad (Zagros Basin, SW Iran)
}

Mohammadsadegh Dehghanian ( $\nabla$ msadeghdehghanian@gmail.com )

Islamic Azad University Bandar Abbas Branch https://orcid.org/0000-0002-9080-4605

\section{Research Article}

Keywords: Sequence Stratigraphy, Asmari Formation, Oligocene, Miocene, Zagros, Iran

Posted Date: March 18th, 2021

DOI: https://doi.org/10.21203/rs.3.rs-315337/v1

License: (9) This work is licensed under a Creative Commons Attribution 4.0 International License.

Read Full License 


\section{Abstract}

Asmari Formation is the thick sequence of carbonate sediment in the range of Oligocene-Miocene which is deposited in the foreland basins of the Zagros and is considered as the original and most famous reservoir rock of Zagros basin. To study of lithostratigraphic units and sequence stratigraphy of this Formation, the section in the southeast of Norabad was selected. Field study indicated that Asmari Formation possessed the thickness of $401.5 \mathrm{~m}$ and included 9 lithostratigraphic units. According to the study of microfacies, Stacking pattern and identification of main sequence level, three depositional sequences including two-second order and one-third order sequence were recognized. The sea-level curve in the studied section indicated that it was correspondence to the global sea level curve. These facies deposited in five environmental sedimentations as follow Open Sea Shelf (Fore Barrier), Bar, Lagoon, Back bar shelf, and Shoal. The environment is part of a carbonate platform that has been formed on an open shelf. In addition, according to the Study of foraminifer dispersion pattern the range of Asmari Formation in Norabad was suggested to be Oligocene (Rupelian- Chattian) to lower Miocene (AquitanianBurdigalian).

\section{Introduction:}

The hydrocarbon reserves and very young tectonic activities of the Zagros Basin attract many researchers. The deposits of the carbonate platform of the Asmari Formation include some of the important oil reservoirs in the world. The Asmari Formation is the youngest reservoir of Zagros reservoir and therefore extensive studies have been performed on this Formation. In the past, this unit of stone was named the calcareous jerib Formations, the Kalhor limestone Formation, and the khamir limestone. But the abovementioned formations are only as part of the Asmari Formation cut-off and does not include all of the formations. The name of this formation is adapted from the Asmari Mountains (southeast of Masjed Soleiman) and the cutting of its type section was measured in the tang-e gel torsh in Asmari Mountain. (Aghanabati, 2004).

In the type section, the Asmari Formation is $314 \mathrm{~m}$ thickness and includes resistant limestone with cream to brown color that is a little intermediate between the Chilean layer and abundant joints. In the type section, Asmari Formation is in Miocene and its lower part is not seen due to the change of facies in Pabdeh Formation. But the complementary part of this formation in Tang-e-Takab Mount Khavir, in the 30 $\mathrm{km}$ from Behbahan, indicates the full features of this formation (Aghanabati, 2004).

The Asmari Formation starts from the Oligocene (Rupelian) and continues to the lower Miocene (Burdigalian) (Motiei, 2004), along with the mountain front and its southern fields, the lower part of the Asmari is in Oligocene. In the northern oilfields of Dezful embayment, this area is characterized by Lower Asmari Anhydrite with the Age of Aquitanian. The upper boundary of the Asmari Formation in the north of the hypothesized line extending from the northern Kharg to the north of the Darkhovin which is consistent with the Gachsaran Formation and in the south it has a gradual elevation of carbonate sands to evaporation and sandy limestone deposits that is almost marginal and lateral facies of the Gachsaran 
Formation (Motiei, 2004). On the northern border of Asmari sedimentary basin, including in the southwest of Sisaket, only the lower part of Asmari is seen and its upper limit is the Razak Formation. In the northern part of the Gurpi Mountain anticline, the upper boundary of Asmari Formation is the Razak Formation and similarly to this phenomenon can be seen in the North of the Anticline of Oil in Lorestan (Motiei, 2004).

In this study the stratigraphic section was selected in the southeast of the Norabad to study the lithostratigraphy and Sequence stratigraphy of Asmari Formation.

\section{Method And Materials:}

To study the sequence stratigraphy of Asmari Formation in the Norabad section, 152 samples with a total thickness of $401.5 \mathrm{~m}$ were collected. Then, some thin microscopic sections were prepared from these samples for performing laboratory examinations, identifying the sedimentary facies, and determining the depth changes of the sedimentary basin. In the present research, investigation, identification, and nomination of the sedimentary facies were conducted based on (Dunham's 1962) ranking.

\section{Geographical and Geological Setting:}

The studied stratigraphic sections in southwestern Iran were located in Fars Province and territory (in Tethys and folded Zagros structural zone) (Fig. 1). The study area, located in the southeast of Norabad and the access to this section was possible through the Norabad-Sepidan Road. Asmari Formation of this section is placed above the Pabdeh Formation under the Gachsaran Formation. (Fig. 2).

\section{Description of the lithostratigraphic units}

This stratigraphic section has 9 lithostratigraphic units as follows:

1- This unit was the first and smallest lithostratigraphic unit of this section and consists of thick-bedded limestone that is located on the sediments of Pabdeh Formation. This unit is $4.4 \mathrm{~m}$ thick and starts with the packstone facies and then turns into a wackestone and ends.

2- This unit was $14.9 \mathrm{~m}$ thick and consists of medium bedded of limestone. This unit begins with packstone facies and ends with the conversion of wackestone.

3- The sedimentary thickness of this limestone unit was $21.6 \mathrm{~m}$ and consists of thick-bedded limestone. This lithostratigraphic unit begins with packstone and then converted to grainstone, wackestone and again packstone, and eventually ends with mudstone. Due to the not very high thickness of this unit, we see the variation and successive variations of sedimentary facies, which indicates the instability of the sedimentary basin during the formation of this unit. 
4- The thickness of sediments in this unit was $18.8 \mathrm{~m}$ and consists of medium-bedded limestone. The sedimentary facies of this unit began with the wackestone and then turned to grainstone and again into wackestone and ended up as the unit 3 with the mudstone. The instability of the sedimentary basin is also present in this section.

5- The unit consists of a thin-bedded of limestone with a thickness of $62.6 \mathrm{~m}$, the beginning of this unit is with the wackestone and ends with grainstone, and alternatively, mudstone facies are also observed.

6- The thickness of sediments in this unit was $30 \mathrm{~m}$ and consists of medium-bedded of limestone. The first facies in this unit are mudstone which ends with the wackestone facies, but in this unit, grainstone and packstone facies are also observed. This unit is also one of the units that show the change in the successive conditions in the sedimentary basin.

7- This lithostratigraphic unit was $20.1 \mathrm{~m}$ thick and consists of thick-bedded limestone. The facies of this unit begin with the continuation of the previous wackestone unit and then converted to mudstone and grainstone, respectively, and eventually ended like the previous one with the wackestone.

8- This unit consists of thin-bedded limestone and the thickness was $36.2 \mathrm{~m}$. It starts with wackestone, which is the continuation of the facies of the former unit and end in wackestone except one case that the facies are converted to grainstone. This unit is the most stable section unit in present study.

9- The last and thickest lithostratigraphic unit includes $192.9 \mathrm{~m}$ thick-bedded limestone which began with the continuation of the wackestone of the previous unit and ended with grainstone and alternately the facies of wackestone, mudstone and grainstone were observed in sediments of this unit. The sequential conversion of facies to each other is a control and volatility index of the sedimentary basin, which has turned this unit into the most unstable unit in terms of changing sedimentary basin conditions. At the end of this unit, the limestone sediments of the Asmari Formation gradually become evaporated sediments of the Gachsaran Formation.

\section{Sequence Stratigraphy:}

Sequence stratigraphy is an important method to analyze the change of the sedimentary environment and regional correlation of sedimentary basin. Sequence stratigraphy is the study of periodic change in Stacking pattern layers in response to accommodation and the rate of sediment supply (Catuneanu 2012). The sequence is formed of somewhat continuously and connectively sequences in terms of the source which in up and down part surrounded by unconformity or equivalent conformity. Sequence boundaries (SB) are the important key to determine the sedimentary sequences which describe by unconformity and conformity adaptive to unconformity (Catuneanu et al. 2009). Preserved sediment between sequence boundaries indicates regression and retrogression which reflected the variation of sea level. The sedimentary package is interpreted according to the sedimentation layer's pattern, sequence position, and type of limiting surfaces (Catuneanu et al. 2010). Each sequence can be categorized into 
sedimentary packages based on the accumulation patterns (Regression and Retrogression) and type of limitation sequence surface. LST, HST, and TST are the recognizable sedimentary packages in the sequence (Catuneanu et al. 2010, 2011). The sequences are deposited during a full cycle of variations of accommodation, but the formation of boundaries of the sequence depends on the periods when accommodation is negative (Mitchum 1977). Identifying the depositional sequences in the uniform carbonate facies seems to be difficult; however, the use of large benthic foraminifera, due to their sensitivity to depth changes, is a good index for determining the sequences (Sarg 1988). Some other studies that have been conducted in recent years on the sequence stratigraphy, depositional environments and facies analysis of Asmari formation are as follows: Wakefield (2003), Dehghanian et al. 2011; Dehghanian et al. 2012; Dehghanian et al. 2013, Habibi (2014); Sadeghi et al. 2017; Dehghanian and Asgari-Pirbalouti 2018; Naseri-Karimvand et al. (2019); Dehghanian 2012, 2017, 2019, 2022.

\section{Description of Bio-sequence Stratigraphy:}

The sequence stratigraphy studies showed three bio-sequences for Asmari Formation which consists of two bio-sequences second-order and one bio-sequence third-order based on sedimentation time requirement in accordance to Vali 1991 study (Fig. 3).

\section{Bio-sequence 1 (Rupelian to Chattian):}

The sediment thickness of this sequence is $122.3 \mathrm{~m}$ and includes the lower part of the Asmari as the Oligocene (Rupelian to Chattian). This sequence consists of lithostratigraphic units 1 to 5 . The lower boundary of this bio-sequence to Pabdeh Formation and its upper boundary with sedimentation sequence 2 is $\mathrm{mfs}$ and the boundary between HST facies with TST was SB2-type. The thickness of the HST in this sequence was $40.9 \mathrm{~m}$ and the thickness of the TEST was $81.4 \mathrm{~m}$. Meanwhile, the end sediments of Pabdeh Formation before converting to Asmari Formation was of the TST type. The sedimentary facies of bio- sequence 1 were mudstone, wackestone, grainstone, and packstone, respectively. The diversity of facies shows the instability of the sedimentary basin during the formation of this sedimentary sequence. Due to the abundance of foraminifera such as: Nummulitesvascus Joly and Leymeri, 1848\ Nummulitesfichteli (Michelotti, 1841), Operculinacomplanata (Defrance, 1822), Amphistegina sp. and also presence of Bivalvia fragments, Gasteropoda, Crinoidea, Echinoderm fragments, Ostracoda and Ostracoda determined the TST system tract consists of open marine and the HST system tract, including bar to lagoon facies. In terms of the parasequence Stacking pattern, the TST facies are retrograde and the HST facies are of the Aggradational type (Fig. 3). The deposition of this sequence requires about 12.6 million years, so, according to Vail et al. (1991), this sequence was a second-order.

\section{Bio-sequence 2 (Lower Aquitanian):}


The thickness of this sequence was $89.6 \mathrm{~m}$ and consists of 6 to 8 lithostratigraphic units, and it consists of medium-bedded limestone, thick-bedded limestone, and thin-bedded limestone. This sequence consists of the lower part of the middle Asmari Formation of the lower Aquitanian (lower Miocene). The lower boundary of this sequence was with sedimentation sequence 1 and its upper boundary with sedimentation sequence 3 of the type mfs and consists of two the HST and TST system tract, respectively. The thickness of the HST and TST sediments was 43.3 and $46.3 \mathrm{~m}$ respectively, and the boundary between these two systems was SB2. The sedimentary facies of this sequence are wackestone, grainstone, mudstone, and packstone, respectively. The presence of Bivalvia fragments, Gastropoda, Echinoderm fragments, Ostracoda, Coral, and also the presence of microfossils such as:

Austrotrilinaasmariensis Adams, 1968, Austrotrilina paucialveolata Grimsdale, 1952, Eulepidina discus, Eames, $1962 \square$ Milliolid which Shows that the sediment of the TST was related to the lagoon facies to the open marine, and the HST system tract is more related to the lagoon to the back bar shelf (Fig. 3). The deposition of this sequence requires about 1.4 million years, so, according to Vail et al. (1991), this sequence was a third-order.

\section{Bio-sequence 3 (Upper Aquitanian to Burdigalian):}

The Bio-sequence 3 has a thickness of $184.1 \mathrm{~m}$ and only includes lithostratigraphic unit 9 and consists of thick-bedded limestone and includes HST. This sequence consists of the end of the middle Asmari and total upper Asmari (Upper Aquitanian to Burdigalian). The lower boundary of this sequence is with sequence 2 of $\mathrm{mfs}$ and the upper boundary to the Gachsaran Formation was SB2. Meanwhile, studying $5.5 \mathrm{~m}$ of the sediments of Gachsaran Formation in this section indicates that the sedimentary facies of the Gachsaran Formation continue to the Asmari formations of grainstone facies, and its system tract was of TST type. In sequence 3 sedimentary facies are frequent in the wackestone, mudstone, and grainstone facies, respectively, and there were no packstone facies in this sequence. Regarding the frequency of foraminifera in this section, such as: Austrotrilinahowchini (Schlumberger, 1893), Austrotrilinaasmariensis Adams, 1968, Peneroplisglynnjonesi Henson, 1950, Peneroplis evolus Henson, 1950, Peneroplisthomasi Henson, 1950, Borelismelo (Fichtel and Moll) curdica Reichel, 1937, Archiashensoni Smout and Eames, 1958, Archiasperculiniformis Henson, 1950, pyrgo sp. And according to the paleoecology of these organisms, the sediments of this system tract can be attributed to the Shoal to Lagoon (Fig. 3). The deposition of this sequence required about 5.9 million years, so, according to Vail et al. (1991), this sequence was a second-order.

\section{Discussion:}

1- Based on studies of microscopic facies, stacking patterns and identification of the principal sequence levels, three sedimentary sequences (including two second-order sequences and a third-order sequence) are identified as follows: 
A. Bio-sequence 1 (Rupelian to Chattian): It includes the open marine facies and the barrier facies of the lower Asmari Formation. This sequence requires 12.6 million years for precipitation and was a secondorder sequence.

B. Bio-sequence 2 (Aquitanian): In this sequence, the TST facies belong to the lagoon to open marine and the HST facies were lagoon to back bar shelf. This sequence is related to the lower part of the Asmari, and has been deposited over 1.4 million years and was a third-order sequence.

C. Bio-sequence 3 (Upper Aquitanian to Burdigalian): It includes Shoal to lagoon and the upper part of the middle Asmari and total of the upper Asmari formation. The sedimentation time is about 5.9 million years old and is considered as the second-order sequencing.

2- Investigating the vertical and adjacent facies variations and comparing them with the present and the ancient environments showed that Asmari Formation in the studied section was formed on a carbonate ramp platform on an open shelf.

3- The lower boundary of Asmari Formation in this section is gradual with Pabdeh Formation and the upper boundary with Gachsaran Formation.

4- According to the study of foraminifera dispersion, the age of sediments of this section was determined as Oligocene (Rupelian to Chattian) to the Lower Miocene (Aquitanian to Burdigalian).

5- Due to the up-rise of Zagros during young Alpine phases and Tethys closure sedimentary basin has changed from the marine (Asmari Formation) to the lagoon-evaporation (Razak Formation).

\section{Conclusion:}

During the Oligocene-Miocene, sedimentation has progressed inside the Tethys Basin and in the interior of the Fars area from the open sea to the shallow marine to Lagoon. Therefore, according to the study of microfacies and field studies in the region, it is concluded that the sedimentation regime in the basin has a direct relationship with the basin tectonic, the geometric shape of the basin and orogeny phases. As a result of the tectonic pressures caused by the collapse of the Arabic plate, the Tethys was closing and during the operation of the young Alpine orogeny phases, uplifting tectonic of Zagros occurred. On the other hand, the operation of the faults in the region was not affected by this fact and it facilitates the uplifts so that the basin gradually becomes less deep during Asmari sedimentation and then becomes lagoon-evaporative and deposits of Gachsaran formation are deposited therein.

\section{Declarations}

\section{Acknowledgment:}

This study was carried out in Islamic Azad University (IAU), Bandar Abbas Branch in Iran, also the author would like to acknowledge the authorities of IAU, Bandar Abbas Branch for financial support and for 
permission to publish this paper.

\section{References}

1. Aghanabati A (2004) The Geology of Iran. Geological Survey of Iran, Tehran. (In Persian)

2. Catuneanu O, Abreu V, Bhattacharya JP, Blum MD, Dalrymple RW, Eriksson PG, Fielding CR, Fisher WL, Galloway WE, Gibling MR, Giles KA, Holbrook JM, Jordan R, Kendall CGStC, Macurda B, Martinsen OJ, Miall AD, Neal JE, Nummedal D, Pomar L, Posamentier HW, Pratt BR, Sarg JF, Shanley KW, Steel RJ, Strasser A, Tucker ME, Winker C (2009) Towards the standardization of sequence stratigraphy, Earth-Sci Rev 92:1-33.

3. Catuneanu O, Bhattacharya JP, Blum MD, Dalrymple RW, Eriksson PG, Fielding CR, Fisher WL, Galloway WE, Gianolla P, Gibling MR, Giles KA, Holbrook JM, Jordan R, Kendall CGStC, Macurda B, Martinsen OJ, Miall AD, Nummedal D, Posamentier HW, Pratt BR, Shanley KW, Steel RJ, Strasser A, Tucker, ME (2010) Sequence stratigraphy: common ground after three decades of development. First Break, 28:21-34.

4. Catuneanu O, Galloway W, Kendall Ch, Maill H, Tucker M (2011) Sequence Stratigraphy: Methodology and Nomenclature. Newsl Stratigr 44(3):173-245.

5. Catuneanu O (2012) International Subcommission on Stratigraphic Classification: guidelines for sequence stratigraphy. GeoConvention. 1-7.

6. Dehghanian M, Khosrotehrani K, Afghah M, Keshani F (2011) Qualitative and quantitative study of the microfacies of the Asmari Formation Bavan Section in northwest Shiraz. Researcher, 3(10):36-40.

7. Dehghanian M, (2012) Microbiostratigraphy and Sequence Stratigraphy of Asmari Formation in Shiraz area, Islamic Azad University Science and Research Branch of Tehran, Faculty of Science Department of Geology, (Ph.D Thesis, Geological Field)

8. Dehghanian M, Khosrotehrani K, Afghah M, Keshani F (2012) Microfacies Study of Asmari Formation in the Northwest and Southeast of Shiraz, Iran. Adv Environ 6(2):556-563.

9. Dehghanian, M, Asgari-Pirbalouti B, Masoumi HR (2013) Oligocene-Miocene Microfacies Study of Asmari Formation (NW-SE of Shiraz, Iran). Iran J Earth Sci 5:66-73.

10. Dehghanian M, Asgari-Pirbalouti B (2018) Bio-sequence stratigraphy of Oligocene deposits in Interior Fars, Zagros Basin, Iran. Himal Geol 39(1):133-143.

11. Dehghanian M, (2017) Microfacies study of Oligo-Miocene in SE Norabad in Fars Province. 1st National Conference on Modern Applied Research of Basic Sciences, Islamic Azad University, Bandar Abbas Branch, 43-51

12. Dehghanian M, (2019) Microfacies study of Oligocene (Asmari Formation) in South Tange-e-Jalab (NW Shiraz). Journal of earth engineering, 2(3). 10-18.

13. Dehghanian M, (2022) Biostratigraphy of the Asmari Formation in northwest of Shiraz (Tang-e Jalab) on the basis of the large benthic foraminifera. Journal of Advanced Applied Geology, In Press 
14. Dunham RJ (1962) Classification of carbonate rocks according to depositional texture, In: W.H. Ham (editor), Classification of carbonate rocks. Am Assoc Pet Geol Bull 1:108-121.

15. Habibi T (2016) Bio- and sequence stratigraphy and microfacies analysis of the Oligocene Asmari Formation at Sepidar Anticline, Interior Fars sub-Basin, SW Iran. HIST BIOL. 28:(4);519-532, DOI: 10.1080/08912963.2014.990388.

16. James GA, Wynd JG (1965) Stratigraphic nomenclature of Iranian oil consortium agreement area. AAPG Bull. 49: 1282-2245.

17. Mitchum RM, Jr, Vail PR, Thompson S (1977) Seismic stratigraphy and global changes of sealevel, part 2: the depositional sequence as a basic unit for stratigraphic analysis. In: Payton, C.E. (ed.), Seismic Stratigraphy - Applications to Hydrocarbon Exploration. Am Assoc Pet Geol Bull 26:53-62.

18. Motiei H (2004) Stratigraphy of Zagros. In: Treatise on Geology of Iran.No.1. Ministry of Mines and Metals. Tehran. Geological Society Iran. (In Persian)

19. Naseri-Karimvand F, Moussavi-Harami R, Mahboubi A (2019) Depositional Environment and Sequence Stratigraphy of the Oligocene-Miocene Deposits North and East of Dehdasht, Izeh Zone, Zagros Basin, Iran. Journal of Sciences, Islamic Republic of Iran (JSCIENCES), 30(2):143 -166.

20. Sadeghi R, Vaziri-Moghaddam H, Mohammadi, E (2017) Biofacies, depositional model, and sequence stratigraphy of the Asmari Formation, Interior Fars sub-zone, Zagros Basin, SW Iran. Carbonate Evaporite 33:489-507

21. Sarg JF (1988) Carbonate sequence stratigraphy. SEPM Special Publications 4:155-188.

22. Vail PR, Audemard F, Bowman SA, Eisner PN, Perez-Cruz C, (1991) The stratigraphic signatures of tectonics, eustasy and sedimentology-an overview. In: Einsele G., Ricken W. and Srilacher A. (Eds.) Cycles and Events in Stratigraphy. Springer-Verlag, Berlin.

23. Wakefield MI (2003) Bio-Sequence Stratigraphy utility of the diversity analysis. Society for Sedimentary Geology, 81-87.

\section{Figures}




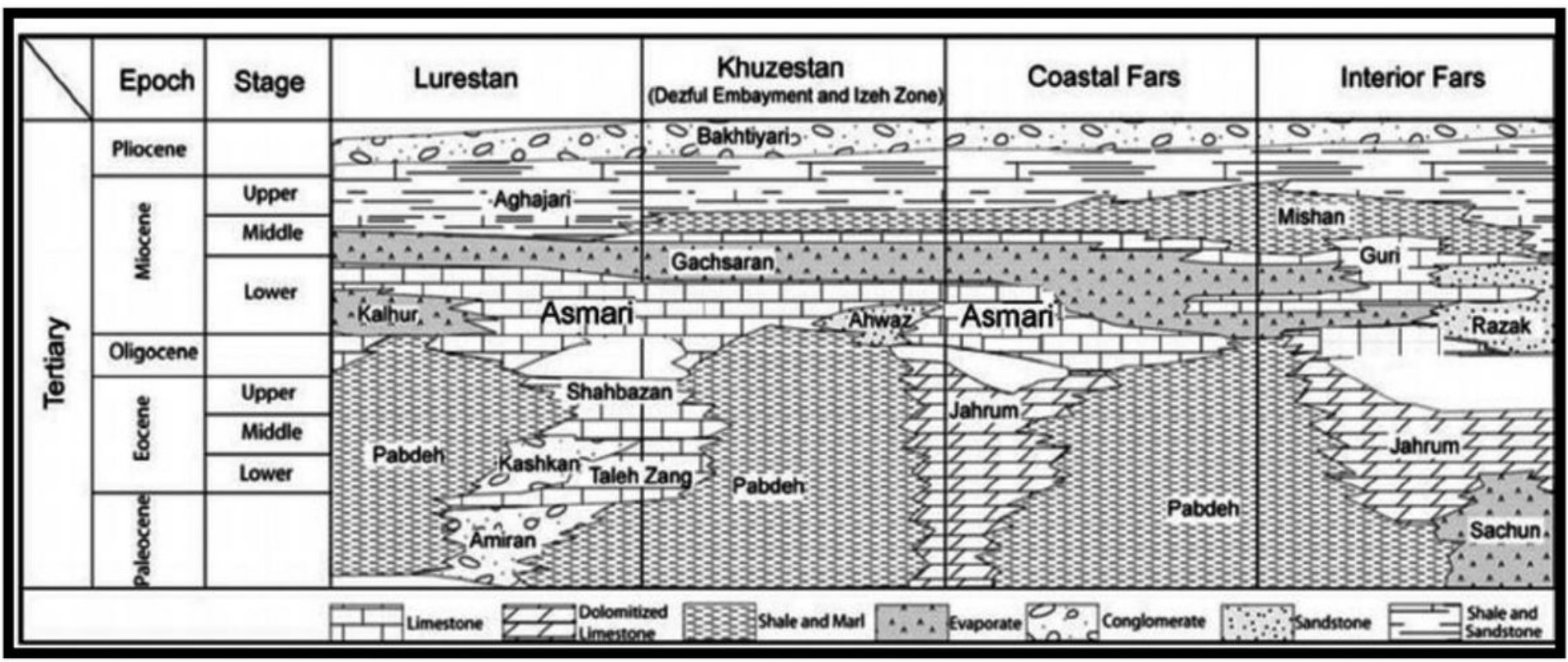

Figure 1

Cenozoic stratigraphic correlation chart of the Iranian sector of the Zagros basin, James and Wynd (1965) 


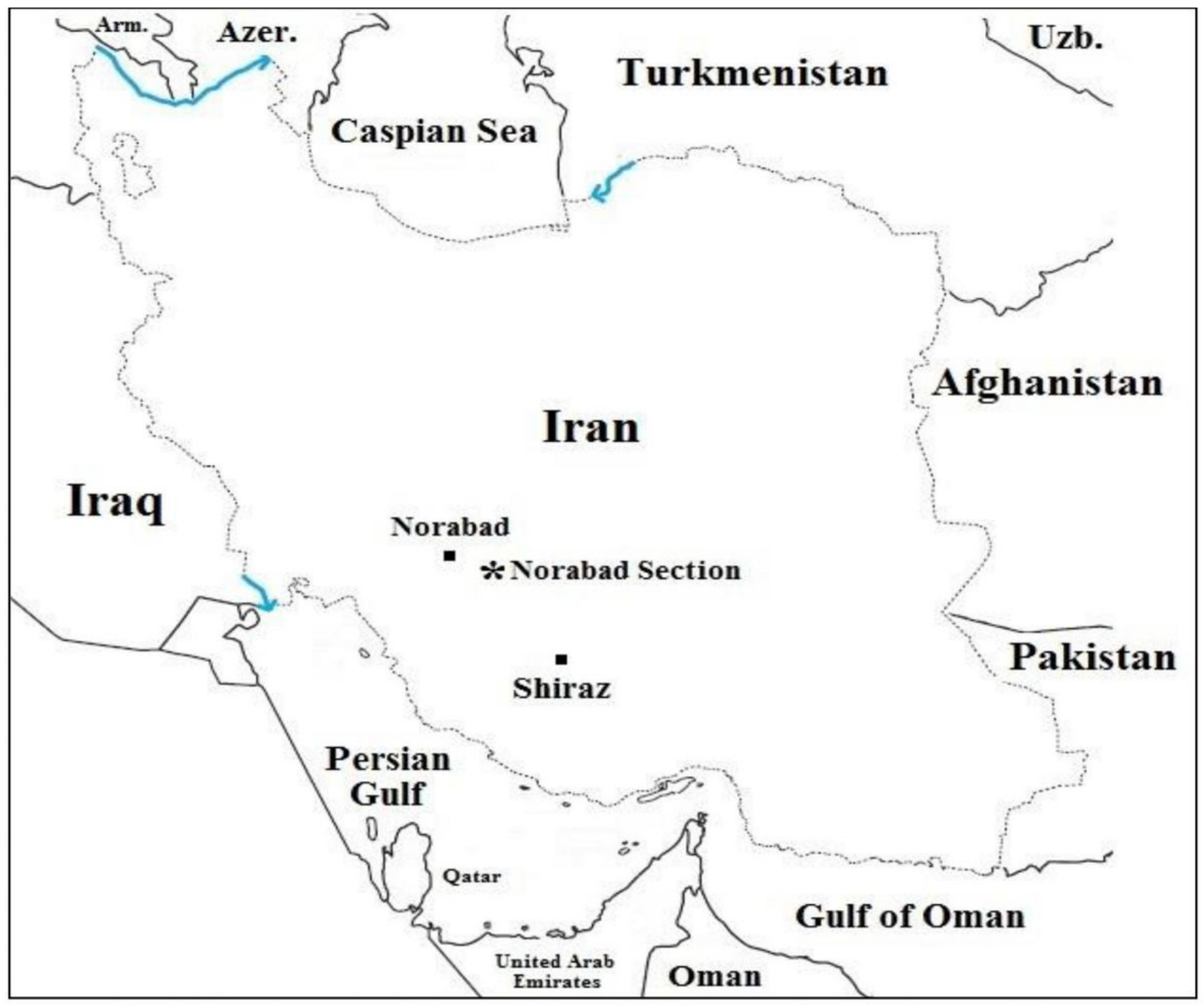

Figure 2

Location map of the studied area in Zagros region, Southwest of Iran. Note: The designations employed and the presentation of the material on this map do not imply the expression of any opinion whatsoever on the part of Research Square concerning the legal status of any country, territory, city or area or of its authorities, or concerning the delimitation of its frontiers or boundaries. This map has been provided by the authors. 


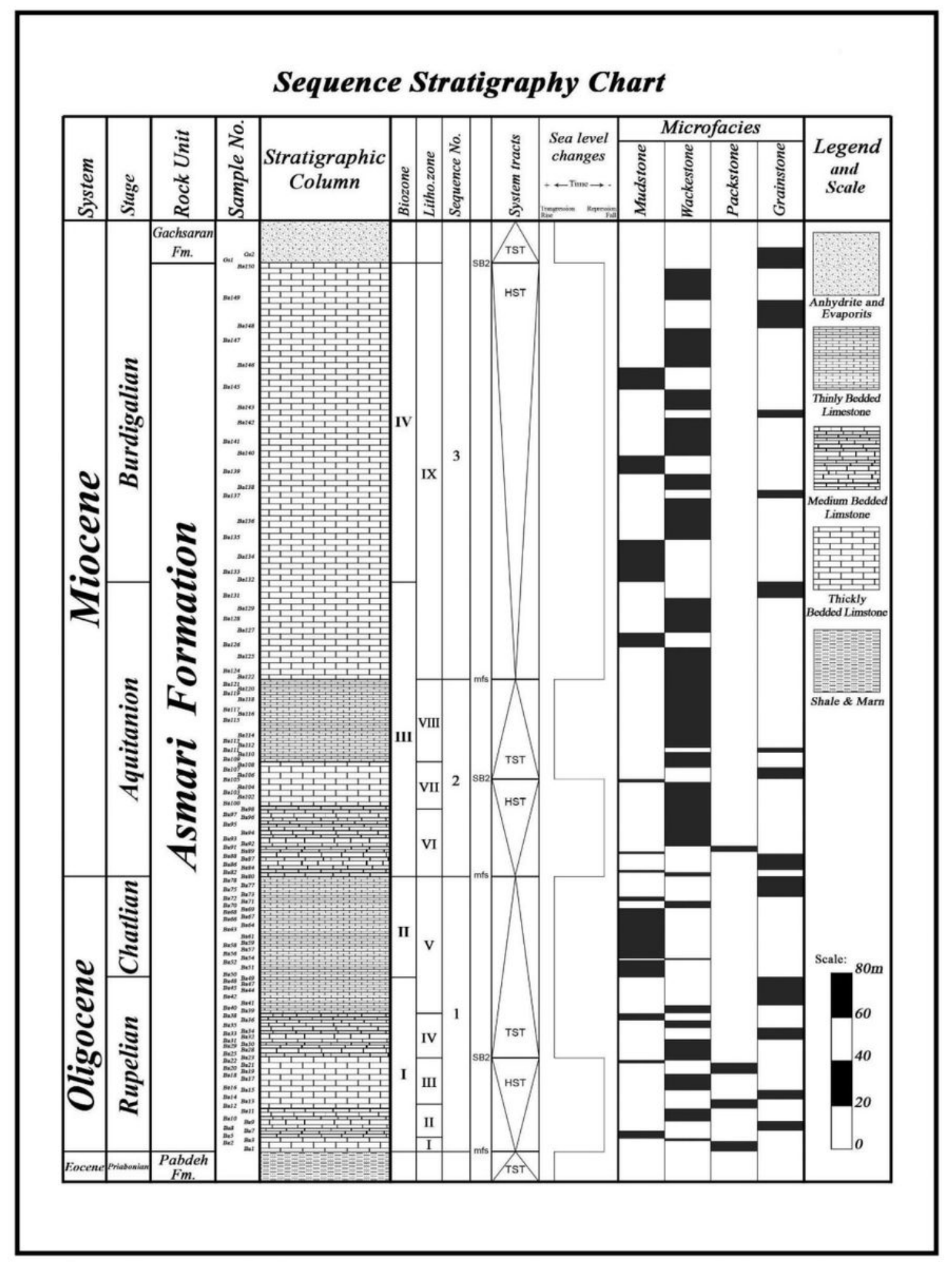

Figure 3

Shows the distribution of stratigraphy and carbonate microfacies and its elements in Norabad section. 
Plate 1:

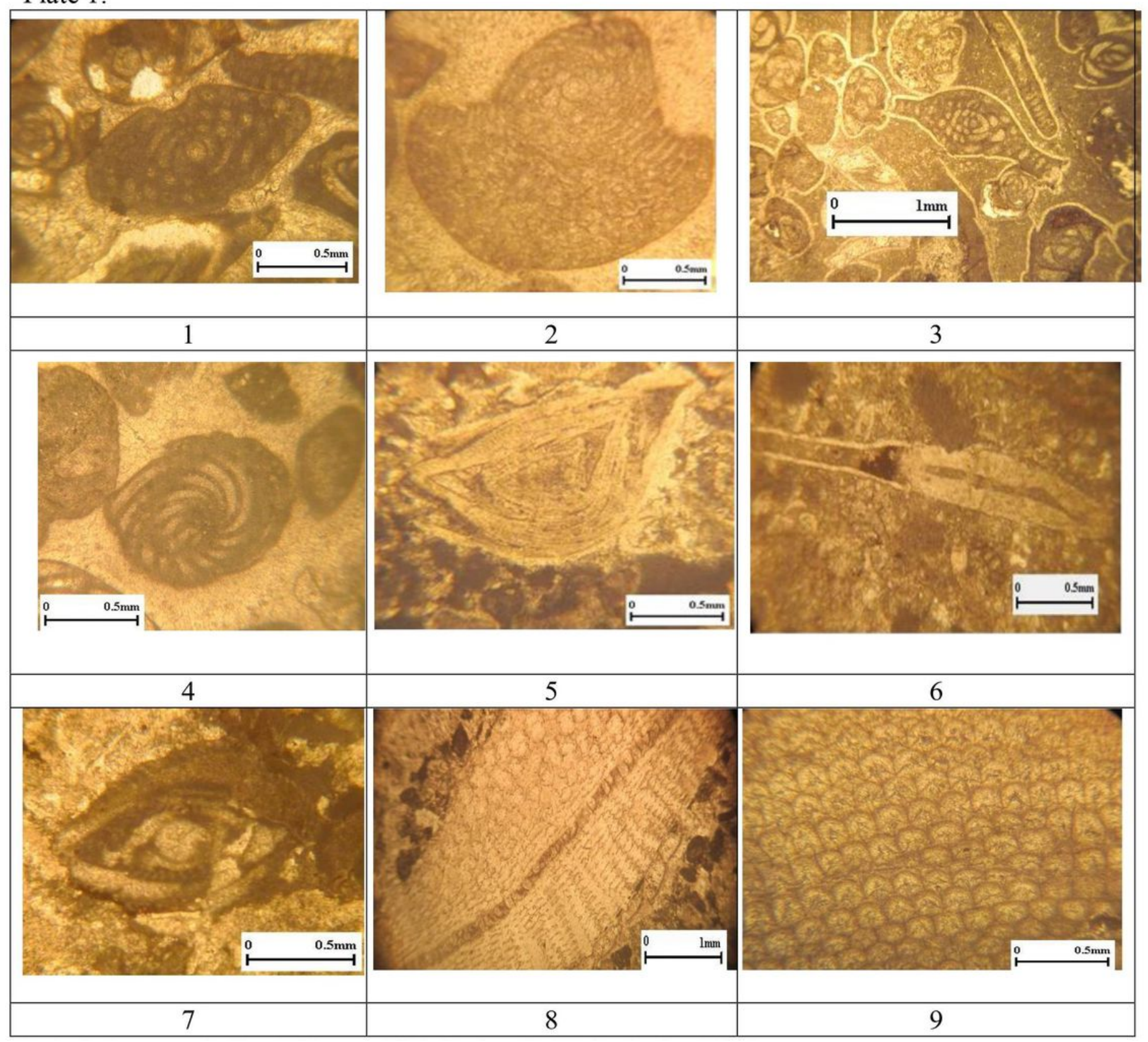

\section{Figure 4}

1. Archaias operculiniformis Henson, 1950, Section: Axial, Aquitanian, X 100, 2. Peneroplis evolutus Henson, 1950. Section: Subequatorial, Aquitanian, X 100, 3. Peneroplis thomasi Henson, 1950, Section: Axial, Aquitanian, X 40, 4. Peneroplis glynnjonesi Henson, 1950, Section: Subequatorial, Aquitanian, X 100, 5. Amphistegina sp., Section: Axial, Rupelian, X 100, 6. Operculina complanata (Defrance, 1822), Section: Subaxial, Rupelian, X 100, 7. Austerotrillina asmariensis Adams, 1968, Section: Axial, Rupelian, X 100, 8. Eulepidina sp., Section: Subaxial, Chattian, X 40, 9. Eulepidina sp., Section: Equatorial, Chattian, X 100 , 